\title{
The South African Labour Movement's Responses to Declarations of Martial Law, 1913-1922
}

\author{
Wessel Visser ${ }^{\bullet}$
}

\begin{abstract}
Summary
The first two decades of South Africa's history is characterised as a period of serious endemic industrial unrest and violence, when the labour movement and capital were involved in regular conflict over labour issues and for control of the country's industrial work force. The level of violence in these conflicts was such that the government as a third party was repeatedly forced to intervene in the disputes and restore law and order by imposing martial law . This paper explores labour's attitude and responses to, as well as the consequences for labour, of the government's declarations of martial law during these disputes and in the First World War.
\end{abstract}

\section{Prologue to Martial Law: The First Military Interventions in Industrial Disputes}

In the early decades of the 20th century no problem loomed so large as the labour problem. The scope and gravity of strikes were increasing. Industrial enterprises became concentrated in huge businesses, and those who ran them refused to make agreements which would allow trade unions to curtail their freedom; they were unwilling to share their authority. Without exception these business enterprises were hostile to the principle of collective bargaining. Skilled workers, who needed three years of apprenticeship, and more of practice to train, became the minority, overwhelmed by specialised unskilled workers who could be underpaid.

Thus action by the workers was tending to become political just at the time when the nature of the state was changing. As the sate itself became more and more an employer, with numerous officials and workers, governments had to decide whether they could stand by while strikes spread to vital sectors in the nation's life. A state whose railwaymen, postmen, and miners were on strike was threatened with paralysis and could therefore ill-afford to stand aloof from industrial disputes. The strike, as a manifestation of collective action by workers, was more and more becoming a warning signal to invite the authorities to intervene actively and military intervention in industrial disputes often had bloody results. ${ }^{1}$

In the cosmopolitan mining community of the early days of the Witwatersrand goldmine industry, immigrants of British origin predominated. ${ }^{2}$ The predominantly British character of the miners, the habits of the British workshop and the tradition of the British trade unions established themselves on the Witwatersrand. ${ }^{3}$ Both the trade union and political

\footnotetext{
Department of History, University of Stellenbosch. Paper presented at the War and Society in Africa Conference, South African Military Academy, Saldanha Bay, 12-14 September 2001.

G. Lefranc: "Strikes. Industrial Relations to 1914" (History of the 20th Century, Vol. I, No. 13, 1968, pp.344,349).

2 D. Ticktin, 'The Origins of the South African Labour Party, 1888-1910' (Unpublished PhD thesis, UCT, 1973), pp.2-3.

3 C.W. de Kiewiet, A History of South Africa. Social and Economic (OUP, London, 1957), pp.211-212.
} 
wings of the (white) South African labour movement were established by immigrants and they were organised in the same way as were similar bodies and movements in Britain. ${ }^{4}$

The predominantly British model of industrial relations that was imported to South Africa is often characterised as the "adversary system" as opposed to the "conciliatory system" of the European continent. Matters such as mining regulations and safety, miner's phthisis, workmen's compensation, the eight-hour work day, prohibition of Sunday work, job reservation for whites and the retention of job colour bars in industry were the contentious issues of negotiation and dispute in the relationship between trade unions and employer organisations, such as the Chamber of Mines. ${ }^{5}$ Therefore, as this paper shall highlight, the first two decades of 20th-century South African labour history is characterised as one of political turmoil as well as of large scale and serious endemic industrial unrest as part of a cathartic process in which the relationship between the state and its subjects in the field of labour took shape.

The first incident that exemplified the increasing intervention of the government in industrial disputes occurred during the general miner's strike of 1907 on the Witwatersrand. The strike started on the Knight's Deep Goldmine on 1 May and eventually spread to more than fifty other mines. It was encouraged by the Transvaal Miner's Association (TMA). The strike, which lasted until 28 July 1907, involved more than 4000 white underground mineworkers. The immediate cause of the strike was that the white miners were called upon to supervise three, instead of two, rock drilling machines. This was an attempt by the mining companies to cut down working costs by reducing the number of overseers and the miners were aware of the implications for white labour. In order to curb the disturbance General JC Smuts, then colonial secretary of the Transvaal, called in imperial troops such as the 2 nd Dragoon Guards. Approximately 1400 imperial troops were posted on the mines to protect mining property and scab labour and to chase away the pickets. ${ }^{6}$

Smuts's conduct in the 1907 strike served as a prelude to ensuing conflicts between capital and labour and in which the state would be compelled to intervene as a result of industrial disputes. The next trail of strength between capital and the state on the one hand and labour on the other took place in 1913. The immediate causes of the 1913 miner's strike started with the appointment of a new manager on the New Kleinfontein Mine near Benoni at the beginning of May. It was also a deliberate move on the part of the mining company to increase its profits by tightening up conditions on the mine. The new manager's first act was to alter the hours of work of underground mechanics who thereby lost their Saturday half holiday. Five of the men concerned refused to comply and left the mine on 10 May 1913, whereupon their trade union, the Amalgamated Society of Engineers, issued instructions to their members not to take the jobs vacated. Bulman, the new manager, then appointed five non-trade unionists in their places and he refused to reinstate the mechanics who had left. After some other white miners at New Kleinfontein refused to work on 26 May, the majority

\footnotetext{
4 E. Roux, Time Longer Than Rope. A History of the Black Man's Struggle for Freedom in South Africa (Victor Gollancz Ltd., London, 1948), p.130; M. Horrell, South African Trade Unionism. A Study of a Divided Working Class SAIRR, Johannesburg, 1961), p.1.

5 N.E. Wiehahn, 'Industrial Relations in South Africa - A Changing Scene' in D.J. van Vuuren et al (eds.), Change in South Africa (Butterworth, Durban, 1983), p.171.

6 I.L. Walker \& B. Weinbren, 2000 Casualties. A History of the Trade Unions and the Labour Movement in the Union of South Africa (SATUC, Johannesburg, 1961), pp.23-24; S.B. Spies, 'British Supremacy and South African Union' in B.J. Liebenberg and S.B. Spies (eds.), South Africa in the 20th Centur (JL van Schaick Academic, Pretoria, 1993), p.42; J. Ploeger, 'Hoofstukke uit die voor- en vroeë geskiedenis van die SAW', Militaria 1(2) 1969, p.52.
} 
of the white workers at the mine voted to support them. A strike was declared and a strike committee was appointed by the miners. ${ }^{7}$

The management, however, refused to negotiate with the strike committee. On 11 June 1913 the management re-opened the mine and took on strike-breakers, or "scabs", to do the work. The strike-breakers were assaulted by the strikers and the strike spread to other mines. By the beginning of July 191319000 white workers from the gold mines and power stations were on strike and all the mines on the Witwatersrand ceased operating. The Minister of Mines, FS Malan, remained confident that the two parties concerned could settle the dispute without government interference, but underestimated the gravity of the situation on the Reef. ${ }^{8}$

Indeed, the tone of The Worker, the official organ of the South African Labour Party (SALP), became increasingly militant. In the issue of 3 July 1913 the paper declared:

"War having been declared in the shape of a general strike on the Rand...The War has now got to be fought, not 'to a finish', as the phrase goes, but to a victory, neither death nor any other alternative being accepted. And it can be done; though it will need more than a Rand strike to do it. For victory means bringing the South African public, and in particular the Union Parliament, to its senses and its knees, and extorting substantial legislation in the worker's interest. It is no use saying the strike will last a week: it must last untill the result is secured...We can still be 'constitutional', that is avoid common crime like murder or arson; but now it is war, the shoe has got to be made to pinch everywhere as tight as it will go, untill they cry for mercy, and really, once it is war, the things usually called murder, arson, destruction of property, and so on, become the principle occupation of armies, and there is no reason in principle, but only in tactics, why they should not be included in the various forms of acute pressure which have to be exercised in industrial war". 9

It was general JC Smuts, a former Minister of Mines and in 1913 the Minister of Defence and of Finance and acting Minister of Justice, who was to play the leading role on government side in the strike. His meeting with the leaders of the strikers on 22 June 1913 was unsuccessful in resolving the deadlock which had arisen between the forces of capital and labour. ${ }^{10}$ Smuts, fearing that the police force could not cope adequately with the situation, had called once again on the imperial garrison in South Africa because the Union Defence Force, although established in 1912, had not as yet been properly constituted. The troops were to protect the mines, power stations, municipal buildings, railway stations and certain private properties against possible attacks from the strikers. The police force was augmented with infantry from units such as the Royal Scots Fusiliers, the Bedfordshire Regiment, the Royal Engineers, the South African Staffordshire Regiment, as well as cavalry detachments from the Tenth Royal Hussars, the First Royal Dragoons, the South African Mounted Riflemen and the Zuidafrikaanse Bereden Schutters. The Royal Field Artillery was also involved. Eventually 2853 policemen, 1681 special constables, 2910 imperial troops

\footnotetext{
7 UG 55 - 1913 Union of South Africa: Report of the Witwatersrand Disturbances Commission, pp.ixvii.

$8 \quad$ S.B. Spies, op. cit., p. 80.

9 The Worker, 3.7.1913, p.1 (Topics of the Week).

10 S.B.Spies, op. cit., p.80.
} 
and 670 members of the citizen force were deployed on the affected areas of the Witwatersrand. ${ }^{11}$

The strike reached its climax on 4 and 5 July 1913. Violence started in the Market Square, Johannesburg on the afternoon of 4 July, when a crowd started stoning the police and a squadron of Royal Dragoons who tried to disperse them. The mob set fire to the goods shed at the railway premises and burnt down the premises of The Star (the mouthpiece of the Chamber of Mines). Corner House (the mining house of H. Eckstein \& Co., considered by the strikers to be a symbol of capitalism) was also attacked when the military and the police opened fire there to try to resore order. The mob looted gun shops and arms and ammunition were distributed. On 5 July 1913 Generals Botha (the Prime Minister) and Smuts arrived in a Johannesburg torn by violence which resulted in the police firing into a mob outside the Rand Club. Altogether 25 people, including innocent bystanders, were killed during the unrest. Others including policemen and soldiers were wounded. ${ }^{12}$ In addition, the military headquarters in Pretoria ordered the revocation of the publication of all newspapers on the Witwatersrand for three days. ${ }^{13}$

In commemoration of the civilian casualties, who had been killed during the shootings, a number of Rand dailies decided jointly to issue a special paper, The News, on Monday 7 July 1913, the day of the victims' funerals. ${ }^{14}$ The News reflected the strikers' strong feeling of resentment at the use of imperial troops during the unrest. The paper published a list of the deceased victims under the headline: "Slaughtered by England's 1s a day assasins". ${ }^{15}$ The Worker also presented a harsh image of the shooting at the Rand Club:

“...the most indescribable scene of cold-blooded brutality ever perpetrated in an industrial conflict...defenceless individuals, including.women and children...were picked off at pleasure, sometimes without sufficient or any warning...It was a calculated, long-drawn murder...an outrage more callous than anything done in war time: a crime which must alter, has already begun to alter the course of this country's social and political history; a diabolical horror which the working class of the Rand will NEVER FORGET and NEVER FORGIVE" ${ }^{16}$

After conferring with representatives of the Chamber of Mines, Botha and Smuts met with a deputation of strike leaders, consisting of A. Watson, J.T. Bain, T. Matthews and J. Hindman, in the Carlton Hotel to effect a settlement. It was agreed that all the strikers would be reinstated and that a judicial committee would be appointed to investigate the workers' grievances. The strikebreakers were to be dismissed but were to be paid a year's salary at

Cd 6941-1913 Union of South Africa: Correspondence Relating to Recent Disorders on the Witwatersrand and the Employment of Regular Troops, pp.1-3; UG 56-1913 Union of South Africa: Judicial Commission of Enquiry into Witwatersrand Disturbances June-July, 1913, pp.39, 65, 79; I.L.Walker \& B. Weinbren, op. cit., p.34; F. J. Grobler, 'Die Invloed van Geskoolde Blanke Arbeid op die Suid-Afrikaanse Politiek van 1886 tot 1924' (Ongepubliseerde D. Litt.-proefskrif, PU vir CHO, 1968), pp.197-200; S.J. Pietersen, 'Stakings aan die Witwatersrand, 1913 - 1914' (Ongepubliseerde MA-tesis, UP, 1970), pp.39,47-48; J. Ploeger, op. cit., pp.57-60.

UG 55 - 1913, pp.xviii-lxvi; UG 56 - 1913, pp.1-28; F.J.Grobler, op. cit., pp.200-209; S.J. Pietersen, op. cit., pp.49-69; I. L. Walker \& B. Weinbren, op. cit., pp.34-36. Cd $6941-1913$, p.9.

14 A.J. Downes, Printers' Saga. Being a History of the South African Typographical Union (Wallachs' Printing \& Publishing Co., Ltd., Johannesburg, 1952), pp.361-362; I.L. Walker \& B. Weinbren, op. cit., p.39. 
government expense. Although not all trade unionists were satisfied, the strike was over and the forces of labour had apparently gained a victory. ${ }^{17}$

General Smuts, however, considered the settlement to be a personal humiliation and a defeat for the government forces. Of J.T.Bain, the secretary of the strike committee, Smuts told Parliament later: "This was the hardest thing I have done in my life - to put my signature together with that of Mr. Bain". Smuts was determined not to be caught unprepared again. He accelerated the organising and training of the Defence Force to be ready the next time should a new industrial upheaval appear. ${ }^{18}$

\section{The $\mathbf{1 9 1 4}$ General Strike and the Declaration of Martial Law}

Indeed, the next industrial dispute between capital and labour in which the government would intervene was only a few months away. According to De Kiewiet, the general strike of 1914 was a continuation and extention of the 1913 strike and was aimed at protecting the interests of white labour. ${ }^{19}$ Industrial relations remained tense for the rest of 1913. Railwaymen had not come out on strike as a body in 1913. Yet their dissatisfaction increased when the cabinet minister in charge of their department, Henry Burton, and the general manager, William Hoy, made it evident by the end of that year that retrenchment of railway workshop employees had become an economic necessity. ${ }^{20}$

In reaction to these announcements the executive of the Amalgamated Society of Railway and Harbours Servants (ASRHS) issued instructions to their members throughout the country to strike unless the government renounced its retrenchments and re-employed dismissed workers. The union's general secretary, HJ Poutsma, asked the Transvaal Federation of Trade Unions to call a general strike. On 13 January 1914 the Federation obliged and took control of the strike. Railway employees from workshops in Pretoria, Johannesburg, Bloemfontein, Durban and Salt River in the Cape Peninsula, as well as coalminers in Natal, were on strike. Acts of sabotage to railway lines were also committed.

This time, however, in anticipation of another fracas that might develop between capital and labour, the government was fully prepared to deal with the situation. Already during the night of 7 and 8 January 1914 the most important railway centres in the Transvaal affected by the strike were put under police protection. On 9 January a number of trade union leaders were arrested and the police confiscated documents at the ASRHS's headquarters in Pretoria. By Proclamation No. 8 of 1914 sales of arms and ammunition in certain Transvaal magisterial districts were prohibited for one month. On 10 January 18 units of the Active Citizen Force, 36 burgher commandos from the Transvaal, the Free State, Natal and the Cape Province, police forces, as well as a number of special constables and volunteers - in all 10 000 troops - were mobilised. The implications of these deployments were that prior to the Federation's declaration of a general strike on the evening of 13 January 1914 involving over 20000 strikers, troops were already in predetermined positions to take control of the affected areas effectively. ${ }^{21}$

17 S.B.Spies, op. cit., p.81; I.L.Walker \& B. Weinbren, op. cit., pp.36-37.

18 H.C. Armstrong, Grey Steel. J.C. Smuts A Study in Arrogance (Methuen \& Co. Ltd., London, Seventh Edition, 1940), pp.224-226.

19 C.W. de Kiewiet, op. cit., p.168.

20 S.B. Spies, op. cit., p.83.

21 Cd 7348-1914 Union of South Africa: Correspondence relating to the recent General Strike in South Africa, pp.46-47, 91; F.S. Crafford, Jan Smuts A Biography (Doubleday, Doran \& Co., New York, 1944), p.92; C.J.Jacobs, 'Die Rol van die Unieverdedigingsmag in die Onderdrukking van die 
As was to be expected, the labour movement protested against the deployment of government forces and the arrest of labour leaders. A Cape Town meeting of railway employees resolved: "This meeting of citizens condemns the action of the Government in calling out the Defence Force to endeavour to overawe the workers, and in illegally arresting the Labour leaders in Johannesburg and Pretoria, and calls for the immediate disbandment of the Defence Force and the release of the leaders". ${ }^{22}$ And a meeting of the Johannesburg district committee of the SALP condemned "the avowed intention of the Government to crush the labour government by brute force". 23

In an address to a crowd of 4000 workers in front of the Trades Hall in Fordsburg, Johannesburg, the headquarters of the Transvaal Federation of Trades, one of the strike leaders used the issue of war as metaphor, as did The Worker during the 1913-strike, to describe in militant terms the confrontation between labour and the government::

"There is a war to the knife. It is absolutely a war of the classes. There is no distinction as to race, creed or colour. The whole of the workers are against the Government, and if the railwaymen go down now the whole of recognised affiliated labour throughout South Africa will go down. If we go down this time it is the end of us, and if the other side go down it is the end of the Government...I can promise you the end of this fight will be victory for the workers and the end of the Government, and placing in power of a Government that will truly represent the feeling of the workers". ${ }^{24}$

On 14 January 1914 the government proclaimed martial law in certain magisterial districts of the Transvaal, the Free State and Natal. ${ }^{25}$ Commandos under Generals JH de la Rey and CF Beyers surrounded the Trades Hall where the strike leaders had entrenched themselves. A thirteen-pounder field-gun of the Transvaal Horse Artillery was trained on the Federation headquarters and an ultimatum was issued to the strikers to surrender. All the members of the Federation were arrested as were hundreds of other strikers. This was followed by the temporary arrest of prominent SALP members such as FHP Creswell, WH Andrews, T Boydell and M Kentridge for contravening martial law regulations. By 18 January 1914 the strike had been crushed with the loss of two lives.

But General Smuts believed that certain foreign-born strike leaders were dangerous men who had revolutionary syndicalist ideas of fomenting revolution and of overthrowing the state by industrial action. Therefore he had nine of these men, HJ Poutsma, JT Bain, GW Mason, W. Livingstone, A Watson, WH Morgan A Crawford, RB Waterston and D McKerrel, removed from their cells in the dead of night on 27 January, conducted in secrecy to a special train and taken to Durban under armed escort. There they were forcibly put aboard the steamship Umgeni, a Bullard-King liner, which sailed from Durban for London on the morning of 30 January. A Cape Town tug was chartered by SALP members and an endeavour made to intercept the Umgeni and take the men off, but this expedient failed. ${ }^{26}$

Nywerheidsonluste van Januarie 1914', Militaria 18(4) 1988, pp.49,51; F.J.Grobler, op. cit., pp.280289; S.J.Pietersen, op. cit., pp.78-94; J.Ploeger, op. cit., pp.66-71.

Cd 7348-1914, p.56.

Cd 7348-1914, p.67.

Ibid., p.78.

See UG 5-1914 Union of South Africa: Martial Law in the Union of South Africa. Proclamation and Regulations issued by the Government and Appointments of Control Officers. 
The publication of newspapers in the Transvaal were also severely affected by restrictions imposed on them by martial law. ${ }^{27}$ For instance, the Transvaal Chronicle, a paper that adopted a sympathetic attitude towards labour, was threatened with closure for allegedly violating regulations pertaining to press censorship. ${ }^{28}$ Through its organ, The Worker, the SALP appealed to all South Africans to condemn the government's action against the strikers. The paper declared that the government should recognise its mistakes. To avoid public disorder the authorities should take the workers into their confidence rather than arming one section of the population against another. Those who were arrested should be released and the retrenchment policy regarding the railway employees should be rescinded. The Worker also sarcastically referred to Smuts as "...the Great General, the unrivalled War Minister, who call out 70000 men [sic] when there is no enemy - has he been giving orders to take action so to irritate the men that some may resist and he be able to pretend that the Rand population is a ruffianly, rebellious people?"29 As a result, the paper was forced to closure under martial law regulations for a period of two months as from the issue of 15 January $1914 .^{30}$

As in the case of the strike of 1913, the strikers in the general strike of 1914 also published their own strike paper in Johannesburg. In January 1914 a "Special 'Strike' Daily Edition" of The Weekly Gazette, a one-penny worker's sheet edited by Fred Horak, who was also a member of the SALP, was published. The paper was explicitly pro-labour and anticapitalistic. ${ }^{31}$ The Gazette strongly identified with the cause of the railway employees during the strike and kept the strikers abreast of the latest developments in the various strike centres. The government's conduct was criticised and the paper stated that the strikers were against the use of violence. ${ }^{32}$

The daily strike editions of The Weekly Gazette appeared on Wednesday 14 January 1914 for the last time. The editor declared that owing to the proclamation of martial law the editorial staff was unable to offer any criticism on the strike situation. Therefore they were unable to publish certain items. On 26 January Horak was charged with contravening Regulation 5 of martial law stipulations, the allegation being that on 15 January he "wrongfully and unlawfully printed, published or circulated a pamphlet, leaflet or other document containing words or information calculated to promote disaffection or excite ill-

pp.41-42: F.J.Grobler, op. cit., pp.289-294; S.J.Pietersen, op. cit., pp.98-100,102-103; C.J.Jacobs, op. cit., p.50.

See UG 5-1914, p.3.

See (SAB) GG Vol. 1483, file no. 62/524, Strike 1914, Censorship of news established under Martial Law: P.J.Sampson-Governor-General, 17.1.1914; Ibid., M.H.M.Burne-Editor Transvaal Chronicle; (SAB) GG Vol. 1483, file no. 62/513, Strike 1914, Protests against action of authorities in threatening to close down paper under Martial Law: P.J.Sampson-Governor-general, 15.1.1914, pp.1-4; Ibid., H.T.Lukin-Editor Transvaal Chronicle, 15.1.1914.

See The Worker, 15.1.1914, p.1 (Strike Notes), p.4 (Leader) and p.5 (South African Labour Party). See also (Cd) 7348-1914, p.245.

(JOB) SALP Collection, Report of "The Worker" Committee to the Annual Conference at East London, 28.12.1914, p.KJ 20.

Cd 7348-1914, p.126; The Weekly Gazette, 8.1.1914; Ibid., 16.3 .1914 (Fred T. Horak of "The Weekly Gazette").

See daily editions of The Weekly Gazette, 8.1.1914 - 14.1.1914. 
feeling". Consequently he was kept in gaol for eleven days, but was discharged after trail and the weekly publication of The Weekly Gazette was resumed on 16 March 1914. ${ }^{33}$

Following the example of the Johannesburg strikers, a strike committee of the Pretoria branch of the South African Typographical Union (SATU) also decided to publish a strike leaflet on 17 January 1914 with I.L. Walker, the branch secretary, as editor. The short-lived Pretoria Strike Herald was distributed free of charge. The first impression produced 10000 copies and there was a great demand for more. The Herald contained items on trade union resolutions regarding the strike, general strike news as well as news on the surrender of the strike leaders in the Fordsburg Trades Hall. It also induced the workers to remain on strike.

However, after the appearance of the first edition the police raided the Pretoria Strike Herald works. Members of the printing staff were arrested on the premises and, like Horak of The Weekly Gazette, charged under martial law with printing matter "calculated to promote disaffection or excite ill-feeling". They were also charged with contravening martial law regulations because the Herald allegedly stated prematurely that the burgher forces were going to be demobilised. During the raid the police confiscated and broke all the printingforms and galleys for the type already set for the second edition of the Herald scheduled for 18 January 1914. A few days later Walker, the editor, was also arrested and charged under martial law with sedition. Eventually the leaflet's printing staff were fined penalties ranging between $£ 20$ and $£ 25$, while Walker was sentenced to imprisonment for one month without the option on one charge and fined $£ 25$ or one month on another. The Pretoria branch of the SATU paid the fines of all its members who were charged. ${ }^{34}$

Although the government forces gained the upper hand in the industrial upheaval of 1914, Smuts over-estimated the outer limits of his powers under martial law with regard to the nine deported strike leaders. This arbitrary action caused an outcry in labour circles in South Africa and Britain. Smuts acknowledged that the deportations were illegal, but explained to Parliament that the proclamation of martial law was necessitated by food shortages on the Witwatersrand as a result of the railway strike, the precarious situation that prevailed with idle black workers in the mining compounds, the threat of property and installations being dynamited by strike extremists, as well as an alleged revolutionary "syndicalist plot" by strike leaders to overthrow the government. Therefore Parliament sanctioned his actions with the passing of the Indemnity and Undesirables Special Importation Act, No. 1 of 1914, despite rigorous protest from the SALP. ${ }^{35}$

Smuts also introduced a Peace Preservation Bill in Parliament. However, The Worker condemned the bill in the strongest terms claiming that, if it should become law, the workers' rights and liberties would be at stake. The bill made provision for legalising martial law under a so-called "control system". The system could be proclaimed at any time and its application meant the abolition of all citizen rights, inviolability of the home and of correspondence, free speech and assembly, striking, picketing, ect. The Worker even hinted that should the bill be

Cd 7348-1914, pp.126,175; The Weekly Gazette, 14.1 .1914 (Proclamation of Martial Law); Ibid., 16.3.1914 (The Closing of The Weekly Gazette Offices by the Authorities) and (Fred T. Horak of "The Weekly Gazette").

Cd 7348-1914, pp.135-136,139,149,151-152,184; I.L.Walker\&B.Weinbren, op. cit., pp.50-51; A.J.Downes, op. cit., pp.397-400; Pretoria Strike Herald, 18.1.1914; Diamond Fields Advertiser Weekly Edition, 24.1.1914, p.24 (Strike Paper Suppressed); The Illustrated Star, 24.1.1914, p.10 ("Strike Herald" Case); Weekly Cape Times and Farmer's Record, 23.1.1914, p.13 (Printing Office Raided).

35 W.K.Hancock, Smuts 1. The Sanguine Years 1870-1919 (CUP., Cambridge, 1962), pp.368-371; S.J.Pietersen, op. cit., pp.95,103-104; T. Boydell, op. cit., pp.91-92. 
passed foreign workers could consider boycotting South African export products in sympathy with their South African fellow-workers. In the outcry that followed and under fierce SALP attacks, the bill was withdrawn, but a Riotous Assemblies Act was put in its place. The act prohibited recruitment to unions by force, banned violent pickting and any strikes in the public utility services, permitted magistrates to prohibit meetings thought likely to endanger public peace, and greatly increased police powers of law enforcement. ${ }^{36}$ Ironically the nine deported strike leaders were brought back to the Union several months later at government expense. $^{37}$

\section{The labour anti-warites and martial law during the First World War}

By 1914 the SALP was at its peak. As a result of the government's bloody suppression of the Witwatersrand 1913 miner's strike, the smothering of the 1914 general strike by martial law and the subsequent deportation of nine strike leaders, Labour ranks swelled with new adherents. The SALP's victory in the March 1914 Transvaal provincial elections was an index of its strength. However, the euphoria generated by these successes concealed the simmering tensions inside the Labour Party. In the more general questions on the means to achieve socialism and the attitude of the party in the event of a "capitalist" war, the conservative right-wing and socialist left-wing of the party continued to compromise uneasily. Therefore the advent of the First World War in August 1914 was most inopportune for the SALP. Differences on the party's policy towards the war would eventually create an irrevocable breach and rupture in the ranks of the labour movement. ${ }^{38}$

The Worker, swayed by Britain's entry into the War, expressed an unequivocal prowar attitude and the majority of SALP members supported the Union's war rôle. ${ }^{39}$ But the opponents of South African participation in the war did not remain idle either. On 25 August 1914 the pacifist section within the party founded the War on War League. C. Wade was chairman, P.R.Roux secretary, and S.P.Bunting treasurer. The only qualification for membership was the signing of a pledge "to oppose this or any other war at all times and at all costs". ${ }^{40}$ The first of thirteen issues of the League's paper - The War on War Gazette - a printed four-page weekly edited by S.P.Bunting, appeared on 19 September $1914 .^{41}$ The paper explained the League's policy towards war as follows:

"If we are ask what is our policy, one answer is, so far a criticism can do it, to stimulate that thinking and to combat the war orators' invitations to shut our eyes and plunge...We of the War on War League have come together from parties and schools, united in a pledge which becomes daily more convinced andmore determined, to

36

R.K.Cope, Comrade Bill. The Life and Times of W.H Andrews, Workers' Leader (Stewart Printing Co., Cape Town, 1943), p.157; The Worker, 12.3.1914, p.1 (Bill for the Abolition of the British Constitution) and p.4 (Leader); Ibid., 9.4.1914, p.4 (Leader).

See The Worker, 6.8.1914, p.6; Ibid., 13.8.1914, p.3 ("Pretoria Notes"); Ibid., 17.9.1914, p.2 (Leader).

B.Hirson \& G.A.Williams, The Delegate for Africa. David Ivon Jones 1883-1924 (Core Publications, London, 1995), p.133; D. Ticktin, 'The War Issue and the Collapse of the South African Labour Party, 1914-15', South African Historical Journal, No. 1, November 1969, pp.59-61,71-72.

See The Worker, 6.8.1914, p.6; Ibid., 13.8.1914, p.3 ("Pretoria Notes"); Ibid., 17.9.1914, p.2 (Leader).

S.Johns, Raising the Red Flag. The International Socialist League and the Communist Party of SouthAfrica, 1914-1932 (Mayibuye Books, UWC, Bellville, 1995), pp.37-38; S.Forman \& A.Odendaal (eds.), A Trumpet from the Housetops. The Selected Writings of Lionel Forman (David Philip (Pty) Ltd., Cape Town, 1992), p.45; The War on War Gazette, 19.9.1914, p.3; The Star, 16.10.1915, p.7 (Election Notes); Ibid., 19.10.1920, p.7 (War-on-War Pledges).

4 S. Forman \& A. Odendaal, op. cit., pp.45-46. 
'oppose this and any othe war'. We publish this Gazette in order to give publicity to all the different considerations on which, and all the different methods by which, it is to be opposed... We have aimed rather at indicating what are conceived by one or another, here and elsewhere in the world, to be the causes and resulting remedies for war; the futile and false ideals and criminal purposes which underlie it; the means to be taken to defeat it". ${ }^{4}$

Naturally, therefore, the Gazette concentrated on anti-war issues. Prominent anti-war labourites wrote articles strongly denouncing the war and the Botha government's participation in it. The conduct of the town Benoni, which during the strikes of 1913 and 1914 was still considered to be "the hotbed of class war" and "the nursery of revolution", but in response to the outbreak of the war formed a labour legion, was severely condemned. The paper alleged that the Union's Defence Force was "despotic" and would "smash democracy" and "take freedom of speech away". The Gazette encouraged its readers to send the editor any information on "enforced recruitng and voluteering and the like". ${ }^{43}$

In addition, anti-war articles by prominent international labour and socialist leaders, such as Karl Kautsky, J. Ramsay McDonald and Prince Kropotkin published in labour and socialst newspapers abroad, were frequently reprinted in The War on War Gazette. Endeavours by Italian, Dutch and American socialists to organise international socialist conferences in an effort to end the war were also welcomed by the Gazette. The protests of Russian socialists, as well as the prominent German anti-war socialists Karl Liebknecht and Rosa Luxemburg, were held as examples to South African anti-warites to follow. On the other hand, the paper criticised the pro-war attitudes of the British Labour Party and the German Social Democratic Party. The gist of the Gazette's articles was that only large international capitalists and arms manufacturers benefited from the war at the expense of the working class. ${ }^{4}$

When the Afrikaner Rebellion of October 1914 broke out in protest against the Botha government's invasion of German South West Africa as part of its contribution to the British war effort, the War on War League proposed to General Smuts, the Minister of Defence, and to Lord Buxton, the Governor-General of South Africa, that it would act as a neutral mediator between the government and the rebels. The offer was, however, declined by both persons. ${ }^{45}$

42 The War on War Gazette, 24.10.1914, p.1 (Our [Policy).

43 See Ibid., 19.9.1914, p.1 (C.Wade: An Open Letter), (F.A.W.Lucas: War is on us now), p.2 (R.J.Hall: The Defence Act) and p.3 (S.P.Bunting: Labour and the War); Ibid., 3.10.1914, p.2 (J.Connolly: Why I Won't Fight!); Ibid., 10.10.1914, p.1 (What Every "Gazette” Reader Should Do) and p.3 (A.Alper: The Cause of the War); Ibid., 17.10.1914, p.4 ("Kiddo": The Government and the Working Class).

The War on War Gazette, 19.9.1914, p.2 (J. Ramsay McDonald: Why we are at War) and p.4 (Prince Kropotkin: Wars and Capitalism); Ibid., 26.9.1914, p.1 (War: What For?) and (Socialist War Points), p.3 (The International Armament Vampire); Ibid., 3.10.1914, p.1 (What "We" are Fighting for), p.3 (The War Traders) and p.4 (The League in Battle); Ibid., 17.10.1914, p.4 (Blood and Iron); Ibid., 24.10.1914, p.2 (Causes of War), p.3 ("Patriots First"), (Socialism or Empire) and (Our German Allies); Ibid., 31.10.1914, p.2 (Sinking Domestic Differences), p.3 ('What "we" are fighting for' again) and (A Spiritual Conflict),p.4 ("T.W.W.": Points for Working Men); Ibid., 7.11.1914, p.2 (American Socialists' Peace Effort) and p.4 (Preparations for Peace); Ibid., 14.11.1914, p.2 (The Proposed Peace Conference), p.3 (The Illusion of War) and (War for Markets), p.4 (A.B.Dunbar: Getting some Light); Ibid., 21.11.1914, p.2 (The Folly of Fighting) and ("F.W.V.": What Profiteth It?).

R.K.Cope, op. cit., p.165; S.Johns, op. cit., p.39; The War on War Gazette, 31.10.1914, pp.1-2 (Civil War!) and (Pax Nobiscum); Ibid., 7.11.1914, pp. 1-2 (Rebellion and Other Topics) and p.2 (F.A.W.Lucas: Civil War); Ibid., 14.11.1914, p.1 (Wanted: Light and Air). 
But The War on War Gazette's constant bitter criticism of the war issue started to annoy the authorities. Referring to the tenth issue of the Gazette the Secretary for Justice made a formal inquiry to the Secretary of Defence whether the paper should not be banned under martial law ${ }^{46}$, which was proclaimed on 12 October 1914 over the whole of the Union and troops were commandeered to suppress the Rebellion. ${ }^{47}$ In the issue involved the Gazette stated that it preached the Sixth Commandment in The Bible, "Thou shalt not kill". Sharp criticism was also expressed against martial law:

"...under cover of Martial Law the regime of serfdom is closing in on us more rapidly than ever. Looking back on the Martial Law cases of the past year or so, we see that we have no longer an independent magistracy, and that our Courts are becoming to be recognised as mere instruments of vengeance on the political or economic opponents of capitalism". 48

Cope alleges that the government feared the rising influence of the War on War League's anti-war propaganda among the public. Apparently the League and the media censor, Hugh Wyndham, differed on the interpretation of the Sixth Commandment in terms of the war situation and its publication in the Gazette. Therefore the paper, as Cope puts it, was "censored out of existence". Eventually The War on War Gazette was forced to close at the end of November $1914 .^{49}$ A notice in the last issue on 28 November 1914 sarcastically hinted at the interference by the censor:

\begin{abstract}
"We regret that owing to an unforseen interposition of Divine Providence and a consequent unusual pressure on our space we are compelled to disappoint our readers unavoidably by a slight delay in the publication of this issue and a crowding out of many articles and items of the type and standard which readers hace come to expect". 50
\end{abstract}

\title{
4. Government by Martial Law: The Rand Revolt of 1922
}

The year 1922 saw the biggest and bloodiest industrial upheaval in South African labour history, which took on the appearance of a civil war on the Witwatersrand. This strike, which was characterised by pitched battles between armed forces of labour and the state, was initiated by a world-wide depression towards the end of 1920 causing the price of gold to drop in 1921. This in turn affected the gold mining industry adversely amidst rising costs of gold production. The wage bill was the one area in which costs could be cut to meet rising expenditure and this made semi-skilled employment the most sensitive area, for blacks and whites were commonly employed in these tasks. In November 1921, in face of the growing economic crisis, the Chamber of Mines gave notice of its intention to abandon the status quo agreement by eliminating a colour bar that protected white labour in any semi-skilled job. In its deliberations with the Chamber of Mines over the wage issue the South African Industrial Federation (founded in the wake of the 1914 general strike) could not handle developments on the gold mines in isolation, because the Chamber's abandonment of the status quo

\footnotetext{
46 (SAB) JUS Vol. 394, file no. 1/424/14, War on War Gazette: Secretary for Justice-Secretary of Defence, 30.11 .1914 (no. 1/424/14).

47 D.W.Krüger, The Age of the Generals. A Short Political History of the Union of South Africa, 19101948 (Dagbreek Book Store, 1958), p.89.

48 The War on War Gazette, 21.11.1914, pp.1-2 (The Time to Strike!). Wyndham-Secretary for Justice, 1.12.1914 (no. 179/23/5/121). 
agreement coincided with a new bid by the coal-owners to depress wages and a refusal by the Victoria Falls Power Company to agree to higher wage demands. Therefore wage negotiations between the SAIF and the Chamber repeatedly broke down.

Meanwhile Percy Fisher, the irregularly elected and subsequently deposed secretary of the South African Mine Worker's Union, announced the formation of a new and militant miners' Council of Action that would push the wage issue to extreme levels with revolutionary intent. Thus pressured, the SAIF balloted its members and brought the coalminers out on 2 January 1922 and the goldminers, engineers and power-workers out on the 10th. It placed the direction of the strike in the hands of an augmented executive and organised the strikers into unofficial commandos across the Witwatersrand and in the country districts to meet force with foce. The impasse between the Chamber of Mines and the SAIF created the conditions under which the revolutionary Council Of Action could seize the initiative and force the SAIF to proclaim a general strike on 7 March 1922 when 22000 workers were on strike. By that time violence and sabotage had already broken out on the Rand. ${ }^{51}$

Initially the government was reluctant to intervene in the dispute and to declare martial law as it was uncertain about the loyalty of the burgher commandos that would constitute an integral part of the Union Defence Force's mobilisation plans. Many members of these commandos could either be strike sympathisers or members of the Nationalist Party (NP) that also sympathised with the strikers, or even be strikers themselves. By February 1922 , as a result of increasing violence by strike commandos, the police started to recruit a citizen guard to patrol the streets of Johannesburg and to protect buildings and property. However, after a general strike was proclaimed on 7 March, it became evident that the police could not deal with the situation. Already by 28 February reinforcements from the Defence Force departed for the Rand. Between 8 and 9 March the Transvaal Horse Artillery, the Transvaal Scottish, the Imperial Light Horse, the South African Medical Corps, members of the Railway and Harbours Brigade, the Pretoria Regiment and the Durban Light Infantry were commandeered.

However, when law and order collapsed, General Smuts, then Prime Minister of the Union, had no choice but to proclaim martial law on 10 March 1922 in all Witwatersrand and some adjacent districts. Simultaneously units of the Active Citizen Force and Citizen Reserve were mobilised by Proclamation No. 51 of 1922. These included the Witwatersrand Rifles, the Rand Light Infantry, the South African Service Corps, more units of the South African Medical Corps, as well as 26 burgher commandos from districts affected by martial law. Influenced by Brig.-Gen. Coen Brits and Lt.-Gen. Sir Jaap van Deventer, both veterans from the Anglo Boer War and other campaigns, the overwhelming majority of the burgher commandos reacted positively to the government's call up. ${ }^{52}$

In 1922 the labour press, as during the strikes of 1913 and 1914, formed an integral part of the workers' struggle against capital. Even before the proclamation of martial law The International, the mouthpiece of the Communist Party of South Africa (CPSA), advocated a militant approach towards the government and the Chamber of Mines:

51 See T.R.H.Davenport, South Africa A Modern History, Third Edition (Macmillan South Africa (Publishers) (Pty) Ltd., Johannesburg, 1987), pp.279-282; A.G.Oberholster, Die Mynwerkerstaking Witwatersrand, 1922 (RGN, Pretoria, 1982), pp.56-160; F.J. van Heerden, 'Die Randse Staking van 1922' (Ongepubliseerde MA-tesis, PU vir CHO, 1965), pp.47-112.

A.G.Oberholster, op. cit., pp.164, 166-167, 170-172; W. Urquhart, The Outbreak on the Witwatersrand March 1922 (Hortors Limited, Johannesburg, 1922), pp.74,80,88,89,91; J.Ploeger, 'Op Brandwag-Drie Eeue Militêre Geskiedenis van Suid-Afrika', Militaria 1(4) 1969, pp.28-29. 
"The answer to the challenge of the Government as expressed in the House of Assembly, must be to EXTEND THE FIGHT, spread the movement, dissipate the forces of the enemy, and create a situation in South Africa which will force the Government for its own safety to stop the struggle by offering some reasonable terms of settlement to the men, and forcing the Chamber of Mines to come off its pedestal". 53

It came as no surprise therefore when the government, after the proclamation of martial law, clamped down on the offices of the CPSA in the Trades Hall in Fordsburg. The police confiscated documents, books and pamphlets and the CPSA's press was damaged beyond repair. W.H.Andrews and S.P.Bunting, who edited the paper, were arrested and held in the Johannesburg Fort for the remainder of the strike. For ten weeks, from the beginning of March until the end of May 1922, The International was suppressed by the authorities. Andrews and Bunting were eventually released and acquitted of a charge of public violence. ${ }^{54}$

On 13 February 1922 the first issue of a so-called "strike paper", Transvaal Post edited by W.F.Mondriaan, appeared. ${ }^{55}$ This bilingual daily championed the cause of white labour during the strike, especially Afrikaner workers with leanings towards the NP and proSALP English workers. For the Transvaal Post the cardinal issue was the clarion call for a "white South Africa". Therefore it implied the preservation of the colour bar in the mining industry as the "only solution" to the strike. Smuts and the Chamber of Mines were severely denounced for their support for the abolition of the colour bar. The Transvaal Post was distributed very effectively by strike committees on the Witwatersrand, even to areas where normal modes of transport were disrupted as a result of the strike. As the paper provided strike news and support for the strike it became immensely popular with the working class on the Rand. Mondriaan claimed that 26000 copies were sold daily. ${ }^{56}$

As a result of the proclamation of martial law on 10 March 1922, publication of the Transvaal Post was prohibited and the police raided its offices and printing press. Apparently the government regarded its contents to be revolutionary and seditious. Mondriaan, the editor, was arrested and detained in Johannesburg. After he was released on bail he fled to Mozambique, where he remained for three months. When martial law was repealed, Mondriaan returned to South Africa. However, in his absence the Transvaal Post went bankrupt and would never appear again. ${ }^{57}$ Oberholster claims that Mondriaan was also

53

54

The International, 3.3.1922, p.2 (Parliament and the Strike).

Ibid., 26.5.1922, p.2 (Forward!) and p.3 (Ourselves); Ibid., 9.6.1922, p.1 (A Weapon for Socialism); Ibid., 6.6.1924, p.3 (His Own Condemnation); R.K.Cope, op. cit., pp.276,278,281,283; S.Johns, op. cit., p.143; E.Roux, S.P.Bunting. A Political Biography (Mayibuye Books, UWC, Bellville, 1993), p. 95 .

See (SAB) JUS Vol. 352, file no. 3/383/22, Authority under Sec. 289 Act 31/17 to produce Interior files in Rex vs. Mondriaan: Secretary for Justice-Justice Department, 24.4.1922 (no. 3/383/22); B.Hirson: The General Strike of 1922 (Searchlight South Africa, Vol. 3, No. 3, October 1993, p.76); Transvaal Post, 13.21922.

(SAWA) W.F.Mondriaan: Herinneringe en ervaringe deur my persoonlik beleef in ' $n$ "Halwe eeu van onreg" II. Die opstand aan die Rand (1922), pp.7-15; (SAB) K4, Martial Law Commission, May-June 1922, p.219; Transvaal Post, 13.2.1922 and 18.2.1922; Die Burger, 22.2.1922, p.6 (Die Stakers en die Pers); Ibid., 21.3.1922, p.8 (Johannesburg Onder Krygswet); B.Hirson (1993), op. cit., p.76.

W.F.Mondriaan, op. cit., pp.23,66-67; L.J.Fourie: Die Staking as Strydmiddel op die Arbeidsmark, met spesiale verwysing na die 1922-staking op die Rand, Ongepubliseerde M.Comm-tesis, US, 1946, p.134; N.Herd, The Revolt on the Rand (Blue Crane Books, Johannesburg, 1966), p.66; Die Burger, 16.3.1922, p.5 (Mnr. Mondriaan en Couzijn Gearresteer). 
involved in a failed plot, as a prelude to a coup, to raid an arsenal at military headquarters in Pretoria. $^{58}$

In the meantime strike commandos attacked the police across the Witwatersrand. At Dunswart on the East Rand strikers attacked the Transvaal Scottish. From Brixton Ridge in Johannesburg strikers fired upon the Transvaal Horse Artillery and a surprise attack was launched on the Imperial Light Horse at Ellispark. The latter was relieved by the Durban Light Infantry. Machine gun attacks were launched and bombs dropped on strike positions in Benoni and Brakpan by government aeroplanes. On 12 March 1922 Gen. Van Deventer launched a counter-offensive on the East Rand and took Benoni and Brakpan the following day. A combined force of Gen. Van Deventer and Brits occupied Springs on 14 March. Thereafter the East Rand was secured.

Also on the West Rand government forces attacked from 11 March and by 14 March were in control of Krugersdorp, Roodepoort, Florida and Langlaagte in Johannesburg. Aeroplanes machine-gunned and bombed the strike positions in Brixton while the Transvaal Horse Artillery opened a bombardment on adjacent positions. Companies of the Durban Light Infantry relieved policemen in positions that were surrounded by strike commandos. However, the Transvaal Scottish took heavy casualties in the skirmish. In Fordsburg strikers were fortified in trenches and behind barricades surrounding the Trades Hall. On 14 March heavy fighting took place between strike commandos and government forces using cannon of the Transvaal Horse Artillery, machine guns and a Whippet tank. The Durban Light Infantry, the Rand Light Infantry, the Transvaal Scottish and burgher commandos were also involved in the fighting. Inevitably the strike commandos had to succumb to the superior numbers and fire power of the government forces, although two extremist ringleaders, Percy Fisher and Harry Spendiff, refused to surrender and committed suicide. Although snipers were still active in Johannesburg the siege of the Fordsburg Trades Hall, the headquarters of the strike committee, broke the back of the strike. On 17 March 1922 the trade unions called off the strike and the next day the demobilisation of the Citizen Reserve began. ${ }^{59}$

The general strike of 1922 took a heavy toll on human lives. Officially 43 soldiers, 86 policemen and 81 civilians were killed, while 133 soldiers, 86 policemen and 315 civilians were wounded in the skirmishes. During and after the strike 4692 persons were arrested and 853 were tried on various charges of murder, high treason and transgression of martial law regulations. Initially 15 persons were condemned to death but eventually only four, H.K. Hull, D.Lewis, C.C.Stassen and S.A. (Taffy) Long were hanged. The rest were sentenced between six months and life imprisonment. A Martial Law Inquiry Judicial Commission came to the conclusion that the government was justified in its endeavours to suppress the strike, but Smuts had to pilot an indemnity act through Parliament to protect the government from the consequences of its actions. ${ }^{60}$

Economically the strikers also paid a heavy price as labour lost to mining capital. Between 12000 and 14000 white workers were unemployed after the strike. The wages of semi-skilled white workers were decreased and they were replaced at an accelerated pace by

\footnotetext{
$58 \quad$ A.G.Oberholster, op. cit., p. 135. 35; F.J. van Heerden, op. cit., pp.114-120; A.G.Oberholster, op. cit., pp. 172-187; J. Ploeger (1969 b), op. cit., p.29; W.Urquhart, op. cit., pp.83-96. 
cheaper black labourers. The statutory colour bar was no longer a guarantee for semi-skilled white workers. ${ }^{61}$

\section{Conclusion}

The political consequences of the 1922 strike would impact profoundly upon the political sphere, especially for labour and the government. Indeed, as certain extremist strike elements sought to overthrow the government and proclaim an industrial republic ${ }^{62}$, Yudelman argues that it was the last sustained challenge from organised white labour to the legitimacy of the South African state up until the present as subsequent strikes never escalated in the form of a systematic, concerted rejection of the state itelf. ${ }^{63}$

The Smuts government's "victory" over the strikers, however, proofed to be shortlived. Smuts' bloody suppression of the strike would contribute to his own political downfall as the resentment and hatred for him, especially in labour circles, reached fever pitch. ${ }^{64}$ Thus The International delivered a scathing verdict on Smuts' handling of industrial unrest:"The whole record of Smuts and his Corner House friends is one long story of dragooning an unwilling people into submission by military force". 65

The formation of an electoral alliance between the NP and the SALP, known as the "Pact", was the most significant political outcome of the 1922 strike. The Pact would, to a large extent, contribute to ousting from power the South African Party government in the general election of $1924{ }^{66}$ The governing alliance of the Pact supported and implemented a protectionist policy for white workers. Therefore the new government was able to wean white labour away from industrial action by promoting a policy of job reservation in skilled trades and also protected semi-skilled white labour. ${ }^{67}$

Rob Davies argues that the state's intervention in labour matters by means of labour legislation in the post 1922 period effectively led to the incorporation, institutionalisation and bureaucratisation of white unions within the state structures, thus eliminating them as a potential militant political threat. According to Davies the Pact had succeeded in bringing about the almost complete political capitulation of the white labour movement to capital. ${ }^{68}$ Yudelman concurs by arguing that the interventionst state embarked upon a program to subjugate and pacify organised white labour by formally co-opting it into the structures of the

61 S.B.Spies, op. cit., pp.152-153; F.J.van Heerden, op. cit., pp.123-124.

62 See B.Hessian: An Investigation into the Causes of the Labour Agitation on the Witwatersrand, January to March, 1922, Unpublished MA thesis, UWits, 1957, pp.92,100,155-161 and R.K.Cope: op.cit.,pp. $225,247$.

D.Yudelman, The Emergence of Modern South Africa. State, Capital and the Incorporation of Organised Labor on the South African Gold Fields, $1902-1939$ (Greenwood Press, Westport, 1983), p.164.

64 W.K.Hancock, Smuts 2: The Fields of Force, 1919-1950 (CUP, Cambridge, 1968), p.150; A.G.Barlow, Almost in Confidence (Juta \& Co., Limited, Cape Town, 1952), p.179.

65 See The International, March 1923-June 1924.

66 J.P.Brits, 'The Last Years of South African Party Rule' in B.J.Liebenberg and S.B.Spies (eds.), South Africa in the 20th Century, pp.154-155,173-175. Africa (UPA, Lanham, 1976), pp. 150,155-156,166-167. 
state. For Yudelman, there can be no doubt that the increased role of the state did bring a virtual end to militant white worker resistance. ${ }^{69}$

Thus the 1922 strike and its political aftermath (the 1924 election) was a watershed in the political and economic history of the (white) South African labour movement. It terminated an era of serious endemic industrial unrest and violence, when labour regarded clashes with capital and the state as "war" and the armed forces of the government as its "enemy". 